\title{
KANDUNGAN LOGAM BERAT NIKEL (Ni) PADA SEDIMEN DAN AIR DI PERAIRAN DESA TAPUEMEA KABUPATEN KONAWE UTARA
}

\author{
Heavy Metal Content of Nickel (Ni) in Sediment and Seawater \\ in Tapuemea Seawaters, North Konawe
}

\author{
Windarsin Wali ${ }^{1}$, Emiyarti ${ }^{2}$, La Ode Alirman $\mathrm{Afu}^{3}$ \\ ${ }^{1}$ Mahasiswa Jurusan Ilmu Kelautan, \\ Fakultas Perikanan dan Ilmu Kelautan, Universitas Halu Oleo. \\ Jl. H.E.A Mokodompit Kampus Hijau Bumi Tridharma Anduonohu Kendari 93232, Telp/Fax: (0401) 3193782 \\ ${ }^{2}$ Surel: emiyarti@ymail.com \\ ${ }^{3}$ Surel: alirmanotsudari@yahoo.co.id
}

\begin{abstract}
Abstrak
Perairan Desa TapuemeaKonawe Utara merupakan salah satu perairan yang memiliki potensi risiko kerusakan lingkungan akibat aktivitas kegiatan manusia di darat. Telah dilakukan pengambilan sampel untuk menentukan konsentrasi logam berat Ni di Perairan Tapuemeapada April 2019. Sebanyak delapan sampel air dan sampel sedimen diambil dandianalisis menggunakan metode Spektofotometridengan alat Atomic Absorption Spectrophotometer (AAS) di Balai Besar Laboratorium Kesehatan Makassar, Sulawesi Selatan. Hasil studimenunjukkan bahwa kandungan

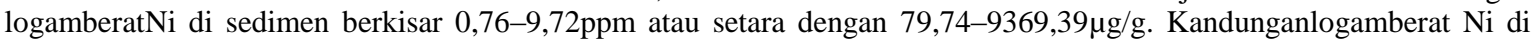
sedimentelah sangat tercemar berdasarkan standar internasionalbakumutu IADC/CEDA Tahun 1997 dantidak sesuai dengan standarkandungan logam berat $\mathrm{Ni}$ di sedimen padakondisiperairanlaut yang normal. Hal yang serupa dijumpai di air, kandungan $\mathrm{Ni}$ dalam air berkisar 0,04-0,23ppm dan telah melebihi Nilai Ambang Batas (NAB)0,05ppm yang ditetapkan oleh KMNKLH No. 51 Tahun 2004 untuk biota laut. Sebaran logam berat Ni terlarut danlogam berat nikel dalam sedimen di Perairan Desa Tapuemea sebagian besar didugaberasaldariaktifitasantropogenik di darat.
\end{abstract}

Kata kunci: logam berat nikel, sedimen, air, Desa Tapuemea

\begin{abstract}
The risk of environmental damage due to anthropogenic activities on mainland has the potential to occur in TapuemeaSeawaters, North Konawe. Sampling has been conducted to determine the concentration of heavy metals Ni in TapuemeaSeawaters in April 2019. A total of eight water and sediment samples were taken and analyzed through the Spectrophotometry method with the Atomic Absorption Spectrophotometer (AAS) at the Health Laboratory Center of Makassar, South Sulawesi. Results of the study showed that the content of heavy metals $\mathrm{Ni}$ in the sediment ranged from 0,76 to $9,72 \mathrm{ppm}$ or equivalent to 79,74 to $9369,39 \mu \mathrm{g} / \mathrm{g}$. The content of heavy metals Ni in sediments has been highly polluted based on international standard IADC/CEDA 1997 quality standards. The contents were very much above their permissible limits set for heavy metal of $\mathrm{Ni}$ in sediment. The similar thing was found in seawater. The Ni concentration ranged from 0,04 to 0,23ppm and has exceeded the threshold value of 0,05 ppm set by KMNKLH No. 512004 for marine biota. Distribution of heavy metals Ni in sediment and seawater in the location was mostly thought to originate from anthropogenic activities on land.
\end{abstract}

Keywords: nickel heavy metal, sediment, water, Tapuemea village

\section{Pendahuluan}

Kabupaten Konawe Utara merupakan salah satu kabupaten yang ada di Provinsi Sulawesi Tenggara, terletak di wilayah pesisir dan memiliki potensi sumber daya pesisir laut yang sangat besar. Kabupaten Konawe Utara juga memiliki cadangan sumber daya mineral berupa nikel (Ni). Pertambangan nikel merupakan salah satu sektor terbesar yang memberikan kontribusi bagi pemerintah untuk pembangunan yang saat ini sedang direalisasikan, khususnya di Kabupaten Konawe Utara. Namun selain memberikan kontribusi bagi pemerintah, pertambangan juga akan menimbulkan dampak buruk terhadap lingkungan sekitar.

Logam berat (heavy metal) dapat menimbulkan dampak pencemaran bagi ekosistem perairan yang menimbulkan penurunan kualitas perairan karena adanya sifat-sifat logam berat yang tidak terurai (undegradable) dan mudah di absorbsi. Logam berat yang ada di perairan pada dasarnya terakumulasi dalam air dan perlahan-lahan akan turun dan mengendap pada dasar 
kemudian terakumulasi dalam sedimen. Logam berat termasuk limbah dalam Bahan Beracun Berbahaya (B3) yang dapat merusak lingkungan hidup.

Pada dasarnya suatu ekosistem memiliki kemampuan pulih diri (self purification) terhadap adanya masukan bahan pencemar ke perairan. Namun jika pencemaran logamnya dalam jumlah konsentrasi yang tinggi maka dapat menyebabkan peningkatan bahan pencemar di perairan dan akan terakumulasi pada sedimen dan air. Limbah dari aktivitas kegiatan manusia akan mencemari perairan, terkhusus pada limbah pertambangan ore nikel disekitar wilayah pesisir. Pencemaran air oleh aktivitas kegiatan pertambangan ore nikel dapat menimbulkan berbagai macam pencemaran logam berat yang berbahaya bagi sistem perairan, termasuk biota-biota yang terdapat di dalamnya. Beberapa logam berat khususnya logam berat nikel banyak digunakan dalam berbagai keperluan. Penggunaan logam-logam berat baik secara langsung maupun tidak langsung atau sengaja maupun tidak sengaja akan mencemari lingkungan. Logam berat, selain mencemari perairan juga akan mengendap pada sedimen kemudian dapat terkonsentrasi dalam tubuh makhluk hidup melalui proses bioakumulasi. Logam berat yang telah terakumulasi memiliki waktu tinggal (residence time) sampai ribuan tahun.

Penelitian dalam rangka pemantauan pencemaran laut oleh logam berat, Pusat Penelitian Oseanografi LIPI Than 2009 telah melakukan serangkaian penelitian di Perairan Pulau Muna, Kabaena dan Buton. Tujuannya untuk mengetahui dampak pertambangan nikel terhadap kandungan logam berat dalam air laut dan sedimen di ketiga perairan pulau tersebut. Hasil menunjukkan bahwa kandungan nikel di dalam air laut relatif masih rendah dan masih sesuai dengan Nilai Ambang Batas (NAB) yang ditetapkan oleh Kepmen LH No. 51 Tahun 2004 untuk biota laut $(0,05 \mathrm{ppm})$.

Hal yang serupa juga dijumpai untuk sedimen dimana kadar nikel relatif rendah dan masih sesuai dengan kadar logam berat dalam sedimen yang dijumpai di perairan laut yang normal (Ahmad, 2009). Penelitian yang sama juga terjadi, dimana kadar nikel di dalam sedimen Teluk Jakarta berdasarkan standar Internasional baku mutu menurut Dutch Quality Standars for Metals in Sediments pada wilayah Muara Angke masih tergolong aman karena masih dibawah nilai level target sedangkan untuk wilayah Muara Pantai Indah Kapuk dan Muara Kamal sudah masuk kategori tercemar sedang (IADC/CEDA, 1997). Mengacu pada baku mutu yang ada, dijelaskan bahwa pada level target, konsentrasi maksimum logam dalam sedimen

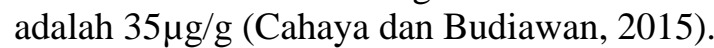

Penambangan nikel di wilayah peisisir akan menimbulkan dampak pencemaran bagi perairan sehingga pencemaran ini dapat mengakibatkan terjadinya penurunan kualitas perairan. Jika penambangan nikel terus menerus dilakukan tanpa adannya pemantauan khusus maka dikhawatirkan dapat menyebabkan peningkatan bahan pencemar di perairan kemudian akan terakumulasi pada sedimen dan air. Akibat kejadian ini dapat menimbulkan perubahan kualitas perairan di Perairan Desa Tapuemea yang telah terkontaminasi oleh aktivitas pertambangan logam berat nikel tersebut, selain itu juga berdampak buruk terhadap organisme akuatik dan masyarakat yang mengambil hasil-hasil laut untuk memenuhi kebutuhan sehari-hari.

Tujuan dilaksanakan penelitian ini adalah mengetahui konsentrasi kandungan nikel dan pola sebarannya dalam sedimen dan air di Perairan Desa Tapuemea.

\section{Bahan dan Metode}

Penelitian ini dilaksanakan pada bulan April sampai Juli, 2019. Lokasi pengambilan sampel sedimen dan air pada penelitian ini dilakukan di Perairan Desa Tapuemea, Kabupaten Konawe Utara. Sedangkan untuk mengolah dan menganalisa sampel sedimen dan air dilakukan di Balai Besar Laboratorium Kesehatan Makassar, Sulawesi Selatan.

Kegiatan observasi awal atau survei pendahulan dilakukan untuk mengetahui gambaran umum lokasi penelitian terkait logam berat nikel di Perairan desa Tapuemea Kabupaten Konawe Utara sehingga lebih mudah untuk menentukan stasiun pengamatan.

Penentuan stasiun penelitian dilakukan secara purposive sampling, yaitu stasiun penelitian ditentukan berdasarkan pada banyaknya aktivitas yang dapat menimbulkan pencemaran perairan Desa Tapuemea Kabupaten Konawe Utara yang dibagi dalam 8 (delapan) stasiun pengamatan dengan jarak antar stasiun $\pm 20 \mathrm{~m}$. 


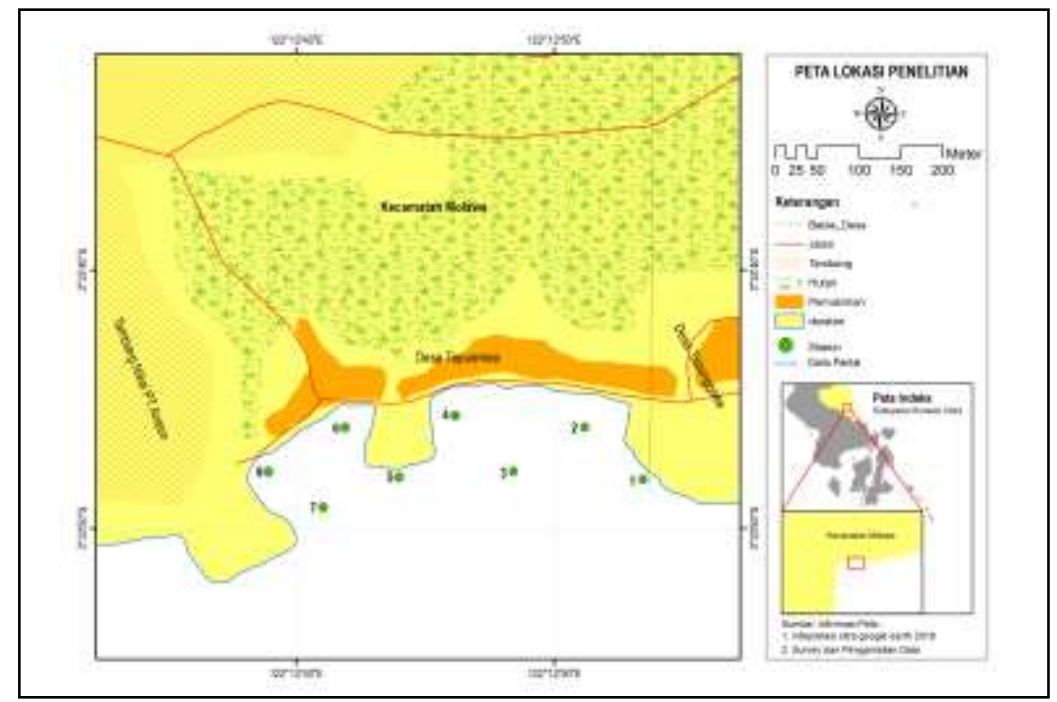

Gambar 1. Peta Lokasi Penelitian

Tabel 1. Titik stasiun pengambilan sampel

\begin{tabular}{|c|c|c|}
\hline Stasiun & Latitude & Longitude \\
\hline I & $03^{0} 33^{\prime} 48.1^{\prime \prime} \mathrm{LS}$ & $122^{0} 12^{\prime} 53.5^{\prime \prime} \mathrm{BT}$ \\
\hline II & $03^{0} 33^{\prime} 46.1$ " LS & $122^{0} 12^{\prime} 51.2^{\prime \prime} \mathrm{BT}$ \\
\hline III & $03^{0} 33^{\prime} 47.8^{\prime \prime} \mathrm{LS}$ & $122^{0} 12^{\prime} 48.4$ " BT \\
\hline IV & $03^{0} 33^{\prime} 45.6^{\prime \prime} \mathrm{LS}$ & $122^{0} 12^{\prime} 46.2^{\prime \prime} \mathrm{BT}$ \\
\hline $\mathrm{V}$ & $03^{0} 33^{\prime} 48.0^{\prime \prime} \mathrm{LS}$ & $122^{0} 12^{\prime} 44.0^{\prime \prime} \mathrm{BT}$ \\
\hline VI & $03^{0} 33^{\prime} 46.1^{\prime \prime} \mathrm{LS}$ & $122^{0} 12^{\prime} 41.9^{\prime \prime} \mathrm{BT}$ \\
\hline VII & $03^{0} 33^{\prime} 49.2^{\prime \prime} \mathrm{LS}$ & $122^{0} 12^{\prime} 41.0 " \mathrm{BT}$ \\
\hline VIII & $03^{0} 33^{\prime} 47.8^{\prime \prime} \mathrm{LS}$ & $122^{0} 12^{\prime} 38.9^{\prime \prime} \mathrm{BT}$ \\
\hline
\end{tabular}

Pengambilan sampel dilakukan secara langsung di lokasi penelitian dengan melakukan 3 kali ulangan serta mengkompositkan sampel secara acak pada setiap stasiun pengamatan. Sampel yang dilakukan adalah sampel sedimen dan sampel air. Pengambilan sampel sedimen untuk mengetahui kandungan logam berat nikel pada sedimen menggunakan pipa paralon dengan cara menancapkan pipa paralon ke dalam sedimen pada tiap stasiun dengan panjang pipa paralon $15 \mathrm{~cm}$ dengan diameter pipa paralon $20 \mathrm{~mm}$. Selanjutnya sampel sedimen dimasukkan kedalam plastik sampel dan diberi label kemudian dimasukkan ke dalam cool box. Pengambilan sampel air untuk mengetahui kandungan logam berat nikel pada air dilakukan dengan mengkompositkan sampel air pada permukaan perairan dengan cara memasukkan air dalam sampel botol hingga $50 \mathrm{ml}$. Setelah proses pengambilan sampel air laut selesai kemudian sampel air ditambahkan dengan larutan asam sulfat $\left(\mathrm{H}_{2} \mathrm{SO}_{4}\right)$ beberapa tetes hingga $\mathrm{pH}<2$, yang berfungsi untuk mengikat kadar logam berat nikel pada sampel air tersebut.

Pengukuran parameter oseanografi fisik kimia dilakukan secara langsung disetiap lokasi penelitian selama 1 (satu) hari yang meliputi kecepatan arus, kecerahan, $\mathrm{pH}$ air, salinitas, suhu, tekstur sedimen dan $\mathrm{pH}$ sedimen. Kecepatan arus diukur dengan menggunakan layangan arus dengan panjang tali 5m, kemudian dihanyutkan pada permukaan air laut. Setelah itu, ditunggu hingga tali tersebut membentang lurus. Dimana, mulai hitung waktu tempuhnya dari dihanyutkan hingga tali membentang lurus tanda perhitungan dihentikan menggunakan stopwatch. Dicatat waktu tempuhnya, kemudian untuk mencari nilai kecepatan arus dengan membagikan jarak tempuh layanglayang arus dengan waktu yang digunakan hingga tali membentang lurus. Hasil yang diperoleh adalah kecepatan arus pada stasiun tersebut. 
Tabel 2. Dutch Quality Standards for Metals in Sediments

\begin{tabular}{cccccc}
\hline Logam $(\mu \mathrm{g} / \mathrm{g})$ & Level Target & $\begin{array}{c}\text { Level } \\
\text { Limit }\end{array}$ & $\begin{array}{c}\text { Level } \\
\text { Tes }\end{array}$ & $\begin{array}{c}\text { Level } \\
\text { Interferensi }\end{array}$ & $\begin{array}{c}\text { Level } \\
\text { Bahaya }\end{array}$ \\
\hline Nikel & $\mathbf{3 5}$ & $\mathbf{3 5}$ & $\mathbf{4 5}$ & $\mathbf{2 1 0}$ & $\mathbf{3 0 0}$ \\
\hline
\end{tabular}

Sumber : IADC/CEDA, 1997.

Pengukuran kecerahan dilakukan dengan cara menurunkan secchi disck sampai hilang dari pandangan. Menurunkan sepertiga meter dan kemudian perlahan-lahan mengangkat secchi disck ke atas dan ke bawah sampai titik hilang yang tetap ditemukan. Pasang jepitan di tali pada titik tali masuk ke air. Mencatat hasil pengukuran.

Mengukur kecerahan perairan menggunakan rumus menurut Carlen (2017) adalah sebagai berikut :

$\mathrm{P}=\frac{x+y}{2}$

Katerangan :

$\mathrm{P}=$ Kecerahan $(\mathrm{cm})$

$\mathrm{x}=$ Jarak secchi disck masih terlihat $(\mathrm{cm})$

$\mathrm{y}=$ Jarak secchi disck tidak terlihat $(\mathrm{cm})$

Pengambilan data $\mathrm{pH}$ air dilakukan dengan cara mencelupkan kertas lakmus ke dalam sampel air laut kemudian dikeringkan. Selanjutnya kertas lakmus tersebut dicocokkan warnanya dengan indikator warna $\mathrm{pH}$ sehingga diperolehlah niai $\mathrm{pH}$ air laut disetiap stasiun.

Pengukuran salinitas dengan menggunakan alat handrefraktometer dengan cara meneteskan sampel air laut ke dalam prisma handrefraktometer, kemudian tutup plat cahaya dan dicatat nilai salinitas yang tercantum pada handrefraktometer.

Pengukuran suhu menggunakan alat thermometer dengan cara mencelupkan ujung thermometer ke dalam badan perairan hingga angka yang tertera pada thermometer menunjukkan nilai konstan/stabil. Suhu yang diukur merupakan suhu permukaan.

Pengukuran tekstur sedimen dengan menggunakan metode pipet volum di Laboratorium Unit Poduktivitas dan Lingkungan Perairan, FPIK-UHO. $\mathrm{pH}$ Sedimen pengukuran $\mathrm{pH}$ sedimen dengan menggunakan alat soil tester dengan cara menancapkan ujung alat pada sedimen hingga batas yang tertera, kemudian terlihat jarum soil tester bergerak pada angka stabil maka dicatatlah nilai $\mathrm{pH}$ sedimen.

Nilai ambang batas baku mutu logam berat nikel dalam air berdasarkan standar Nasional yang ditetapkan oleh KMNKLH No.
51 Tahun 2004 untuk biota laut adalah $0,05 \mathrm{ppm}$. Sedangkan untuk nilai baku mutu logam berat nikel yang terdapat di sedimen berdasarkan standar Internasional baku mutu menurut Dutch Quality Standars for Metals in Sediments berdasarkan sumber IADC/CEDA, (1997).

Level target, jika konsentrasi kontaminan yang ada pada sedimen memiliki nilai yang lebih kecil dari level target, maka substansi yang ada pada sedimen tidak terlalu berbahaya bagi lingkungan. Level limit, jika konsentrasi kontaminan yang ada di sedimen memiliki nilai maksimum yang dapat ditolerir bagi kesehatan manusia maupun ekosistem. Level tes, jika konsentrasi kontaminan yang ada di sedimen berada pada kisaran nilai antara level limit dan level tes, maka dikategorikan sebagai tercemar ringan. Level intervensi, jika konsentrasi kontaminan yang ada di sedimen berada pada kisaran nilai antara level tes dan level intervensi, maka dikategorikan sebagai tercemar sedang. Level bahaya, jika konsentrasi kontaminan (hanya untuk logam berat) berada pada nilai yang lebih besar dari baku mutu level bahaya maka dikategorikan sangat tercemar.

\section{Hasil dan Pembahasan}

Umumnya perairan mengalami proses sedimentasi, dimana logam yang tidak mudah larut mengalami proses pengenceran yang berada di kolom air lama kelamaan akan turun ke dasar dan mengendap dalam sedimen. Kadar logam berat tertinggi dapat dilihat dari tekstur sedimennya. Semakin kecil butiran partikel (fraksi sedimen) maka daya serapnya semakin tinggi sehinnga semakin bersifat lempung/lumpur semakin tinggi kandungan nikel pada sedimen. Hal ini berdasarkan pernyataan Said et al., (2009) bahwa, akumulasi logam berat dalam sedimen dipengaruhi oleh jenis sedimen, dimana semakin kecil jenis butiran sedimen maka semakin besar daya akumulasinya dalam sedimen.

Tingginya kadar logam berat pada sedimen di stasiun VIII menunjukkan bahwa 
terjadi akumulasi dalam sedimen. Hal ini terlihat dari komposisi (fraksi) sedimen (Tabel 4) yang berupa debu, dimana debu tersebut mempunyai pori-pori yang cukup kecil, daya adsorbsinya cukup tinggi, sehingga kadar logam berat yang didapat cukup tinggi (Tabel 6). Stasiun VIII berada dekat dengan jetty tempat penampungan ore nikel dan berdekatan dengan pemukiman sehingga terkena langsung dampak dari aktivitas kedua kegiatan tersebut. Hal ini juga dimungkinkan karena kondisi stasiun VIII yang tertutup, sehingga terlindung dari gelombang. Kondisi tersebut menyebabkan sirkulasi air menjadi terbatas dan partikel-partikel tersuspensi dalam air cenderung terdeposit ke dasar perairan. Hal ini berdasarkan pernyataan Sriwahyuni et al., (2015) bahwa, butiran halus banyak dijumpai di perairan yang relatif tenang. Semakin kecil butiran sedimen maka semakin tinggi konsentrasi logam berat di perairan.

Komposisi sedimen yang berbeda disetiap stasiunnya juga diduga mempengaruhi konsentrasi nikel pada sedimen di Perairan Desa Tapuemea. Fraksi sedimen di Perairan Desa Tapuemea pada setiap stasiun ditampilkan pada Tabel 4. Fraksi di stasiun VIII didominasi oleh fraksi debu sedangkan distasiun lainnya didominasi fraksi pasir (Tabel 4). Fraksi pasir disemua stasiun berkisar 46,90-94,3\%, liat berkisar 0,54-5,51\% dan debu berkisar $2,70-47,72 \%$. Tipe sedimen dapat mempengerahui kandungan logam berat dalam sedimen. Hal ini berdasarkan pernyataan Ana (2010) bahwa, sedimen berbentuk lumpur memiliki kadar logam berat yang cukup tinggi dibandingkan pasir. Hal ini karena lumpur memiliki pori-pori yang cukup kecil sehingga daya absorbsinya cukup besar dibandingkan pasir yang memiliki pori-pori besar sehingga daya absorbsinya relatif kecil.
Fraksi sedimen stasiun I hingga VII didominasi oleh pasir. Hal ini diduga karena stasiun-stasiun tersebut mempunyai arus yang cukup besar dan lebih dinamis sehingga hanya material yang cukup besar saja yang dapat terendapkan. Ukuran butiran sedimen yang bervariasi disetiap stasiun pengambilan contoh diperkirakan berasal dari materi yang ada di lingkungan sekitar sehingga mempengaruhi pembentukan sedimen. Variabilitas air laut seperti gelombang dan arus diduga juga menjadi salah satu faktor penyebab terjadinya perbedaan komposisi tekstur (fraksi) pada stasiun pengambilan contoh. Hal ini berdasarkan pernyataan Ioramullah (2014) bahwa, kecepatan arus yang berbeda-beda dapat menyebaban tekstur sedimen yang berbeda-beda. Semakin tinggi kecepatan arus maka substrat dasar memiliki tekstur yang semakin besar.

Hasil pengukuran $\mathrm{pH}$ sedimen disetiap stasiun pengamatan (Tabel 3) menunjukkan nilai yang tidak jauh berbeda yaitu $6,8-6,9$. Hal ini dipengaruhi oleh tingginya sedimentasi yang membawa banyak lumpur atau butiran-butiran dari kolom hingga ke dasar perairan yang memiliki kandungan bahan organik yang tinggi. Nilai $\mathrm{pH}$ yang signifikan ini disebabkan letak stasiun berdekatan dengan rumah pemukiman sehingga mendapat ativitas langsung dari limbah rumah tangga. Hal ini berdasarkan pernyataan Ioramullah (2014) bahwa, naiknya $\mathrm{pH}$ disuatu perairan disebabkan karena aktivitas dari kegiatan manusia di darat misalnya limbah rumah tangga. Terjadinya peningkatan maupun penurunan $\mathrm{pH}$ diduga akibat faktor dekomposisi oleh mikroorganisme (Zaizafun et al., 2017). Menurut Rompas et al., (2009) bahwa, perubahan $\mathrm{pH}$ dipengaruhi oleh perubahan gas $\mathrm{CO}_{2}$ dan $\mathrm{CO}_{3}{ }^{-}$.

Tabel 3. Parameter Fisik Oseanografi

\begin{tabular}{ccccccc}
\hline \multirow{2}{*}{ Stasiun } & \multicolumn{7}{c}{ Parameter } \\
\cline { 2 - 7 } & $\begin{array}{c}\text { Arus } \\
(\mathbf{m} / \mathbf{d e t i k})\end{array}$ & $\begin{array}{c}\text { Kecerahan } \\
(\mathbf{m})\end{array}$ & $\begin{array}{c}\text { Kedalaman } \\
(\mathbf{m})\end{array}$ & $\mathbf{p H}$ & $\begin{array}{c}\text { Salinitas } \\
(\mathbf{p p t})\end{array}$ & $\begin{array}{c}\text { Suhu } \\
\left({ }^{\mathbf{0}} \mathbf{C}\right)\end{array}$ \\
\hline I & 0,024 & 70 & 3 & 7 & 14 & 32 \\
II & 0,031 & 90 & 2 & 7 & 10 & 28 \\
III & 0,037 & 80 & 2 & 7 & 13 & 32 \\
IV & 0,040 & 80 & 2 & 7 & 14 & 34 \\
V & 0,028 & 80 & 3 & 7 & 10 & 30 \\
VI & 0,040 & 60 & 2 & 7 & 15 & 33 \\
VII & 0,041 & 70 & 4 & 7 & 14 & 32 \\
VIII & 0,024 & 60 & 2 & 7 & 10 & 28 \\
\hline
\end{tabular}


Tabel 4. Parameter Kimia Oseanografi

\begin{tabular}{cccccc}
\hline \multirow{2}{*}{ Stasiun } & \multicolumn{3}{c}{ Fraksi Sedimen* } & \multirow{2}{*}{ Kelas } & \multirow{2}{*}{ pH Sedimen } \\
\cline { 2 - 4 } & Debu (\%) & Liat (\%) & Pasir (\%) & & \\
\hline I & 22,98 & 2,95 & 74,07 & Pasir Berlempung & 6,9 \\
II & 3,39 & 4,23 & 92,37 & Pasir & 6,8 \\
III & 2,70 & 2,75 & 94,54 & Pasir & 6,8 \\
IV & 3,09 & 5,51 & 91,39 & Pasir & 6,9 \\
V & 14,69 & 2,91 & 82,40 & Pasir Berlempung & 6,9 \\
VI & 13,79 & 0,54 & 85,66 & Pasir Berlempung & 6,9 \\
VII & 3,94 & 1,66 & 94,40 & Pasir & 6,9 \\
VIII & 47,72 & 5,38 & 46,90 & Lempung Berpasir & 6,8 \\
\hline
\end{tabular}

Keterangan : *Tekstur Sedimen Menggunakan Metode Titrasi Pipet Volum.

Tabel 5. Kadar Kandungan Nikel pada Air

\begin{tabular}{cccc}
\hline Stasiun & Ni pada Air $(\mathbf{p p m})$ & NAB $(\mathbf{p p m})^{*}$ & Keterangan \\
\hline I & 0,23 & & Melebihi \\
II & 0,05 & & Tidak Melebihi \\
III & 0,06 & 0,05 & Melebihi \\
IV & 0,04 & & Tidak Melebihi \\
V & 0,07 & Melebihi \\
VI & 0,06 & Melebihi \\
VII & 0,05 & Tidak Melebihi \\
VIII & 0,20 & Melebihi \\
\hline
\end{tabular}

Keterangan* : Nilai Ambang Batas Baku Mutu Nikel pada Air Berdasarkan KMNKLH No. 51 Tahun 2004.

Tabel 6. Kadar Kandungan Nikel pada Sedimen

\begin{tabular}{ccc}
\hline Stasiun & Ni pada Air $(\mathbf{p p m})$ & NAB $(\mathbf{p p m})^{*}$ \\
\hline I & 6,26 & \\
II & 0,88 & \\
III & 0,76 & 0,05 \\
IV & 0,85 & \\
V & 0,99 & \\
VI & 1,70 & \\
VII & 4,21 & \\
VIII & 9,72 & \\
\hline
\end{tabular}

Nilai $\mathrm{pH}$ akan mempengaruhi konsentrasi logam berat di perairan, dalam hal ini logam berat akan lebih tinggi pada $\mathrm{pH}$ rendah, sehingga menyebabkan toksisitas logam berat semakin besar. Hal ini berdasarkan pernyataan Alimah et al., (2014) bahwa, penurunan $\mathrm{pH}$ akan menyababkan daya racun logam berat semakin tinggi. Hal ini diperkuat oleh Rochyatun et al., (2005) yang mengatakan bahwa, dikarenakan logam yang sukar larut, dengan demikian logam lebih banyak diendapkan di dasar perairan.

Kadar kandungan nikel disemua stasiun berkisar 0,04-0,23ppm. Kadar tersebut telah melebihi ambang batas (kecuali stasiun II, IV dan VII) yang ditetapkan oleh KMNKLH No. 51 Tahun 2004 tentang batas maksimal cemaran logam berat nikel dalam air yaitu sebesar 0,05ppm. Hal ini menunjukkan bahwa Perairan Desa Tapuemea telah tercemar dan tidak sesuai untuk kehidupan organisme perairan. Hal ini sesuai dengan pernyataan Ana (2010) bahwa, logam berat di perairan dapat menimbulkan efek toksik jika keberadaannya telah melebihi nilai ambang batas sehingga akan berdampak langsung, tidak hanya pada organisme akuatik, ekosistem perairan juga secara tidak langsung 
berdampak kepada kesehatan manusia yang mengkonsumsi hasil laut daerah yang telah tercemar tersebut. Hal ini diperkuat oleh Esye et al., (2015) yang mengatakan bahwa, sifat logam berat yang sulit terurai sehingga mudah terakumulasi dalam lingkungan perairan juga pada beberapa kasus, dapat menyebabkan kematian baik itu kepada organisme, ekosistem ataupun manusia. Menurut Ahmad (2009) bahwa, keracunan logam berat biasanya disebabkan kebiasaan memakan makanan yang berasal dari laut misalnya ikan, kepiting dan tiram yang sudah terkontaminasi akibat cemaran logam berat di perairan. Hal ini didukung oleh Sriwahyuni et al., (2015) bahwa, nikel jika terlarut dalam badan perairan pada konsentrasi tertentu akan berubah fungsi menjadi toksik bagi kehidupan perairan dan manusia yang mengkonsumsi hasil laut tersebut.

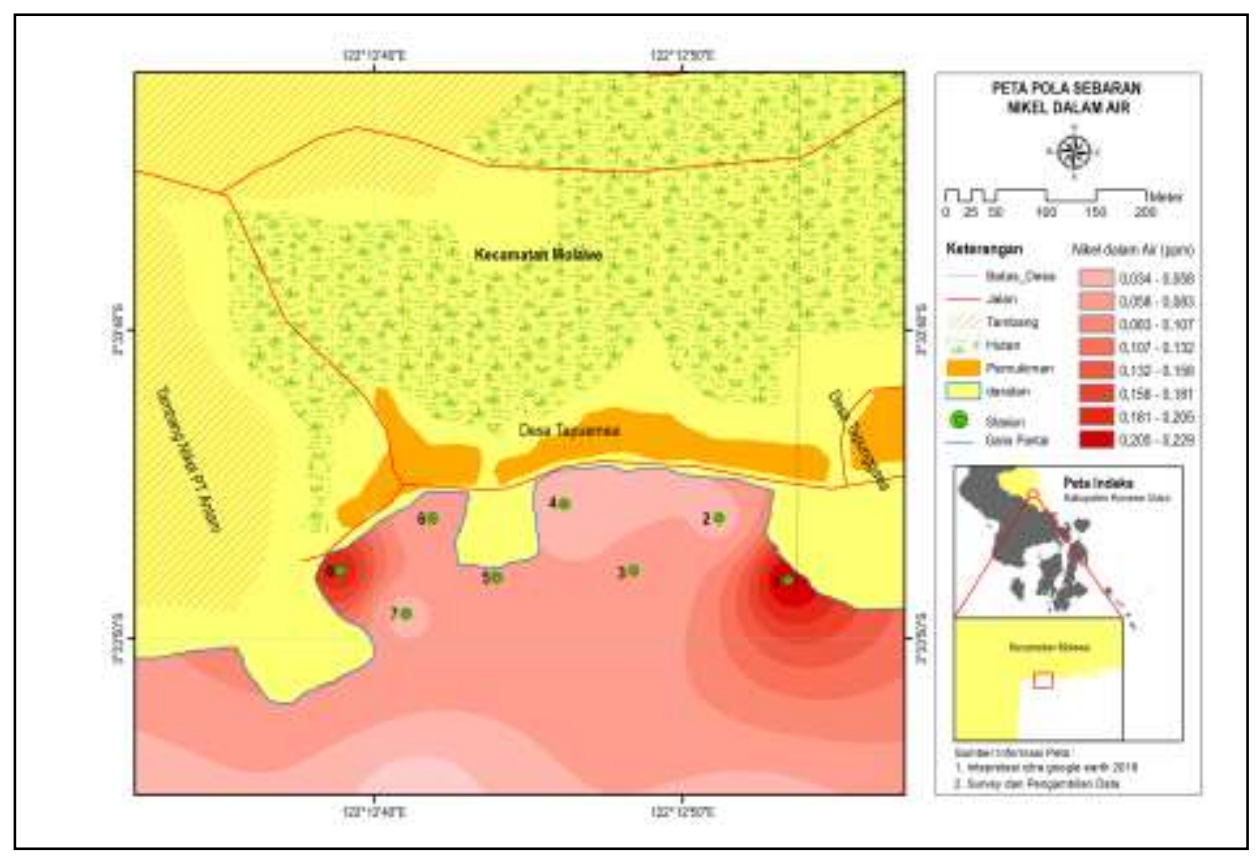

Gambar 4. Pola Sebaran Nikel dalam Air

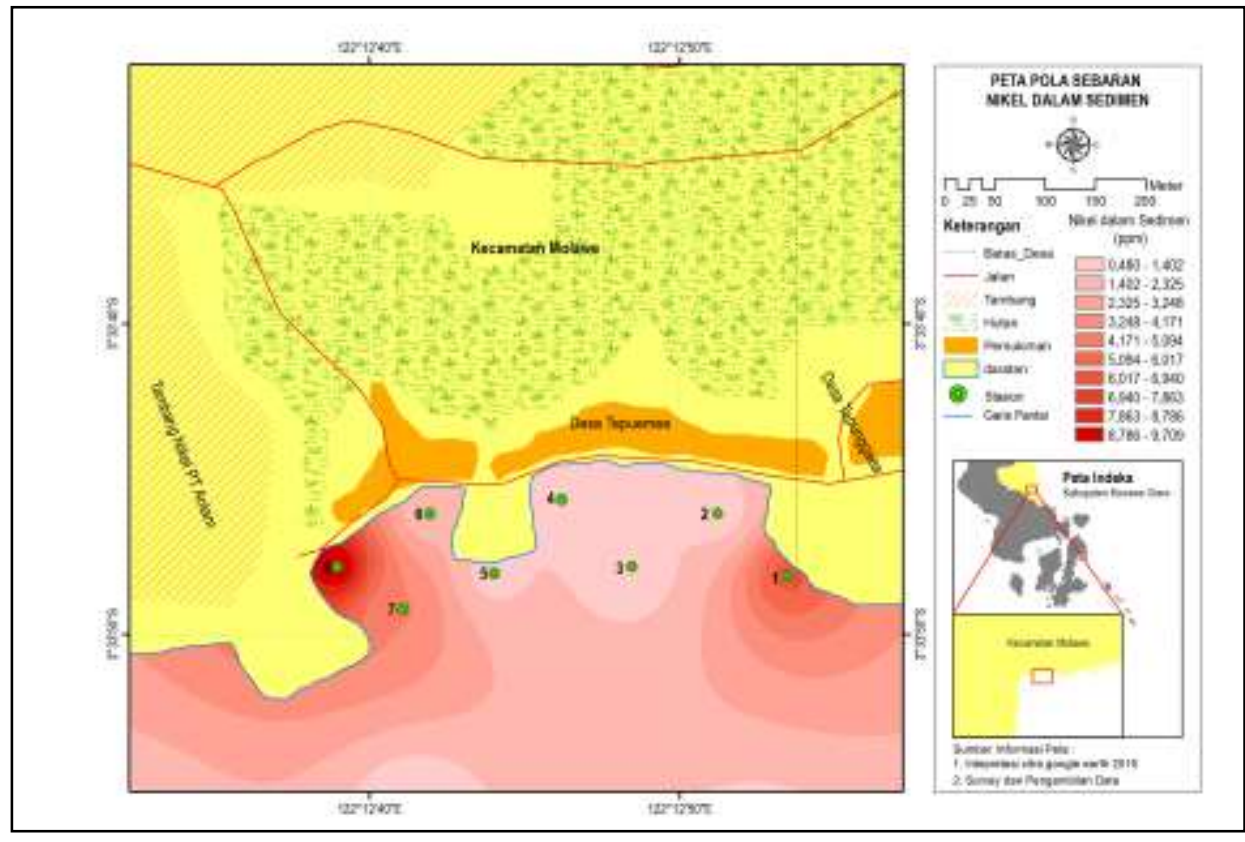

Gambar 5. Pola Sebaran Nikel dalam Sedimen 
Tingginya nilai kandungan nikel di Stasiun I (Tabel 5) diduga akibat adanya timbunan tanah yang dilakukan oleh masyarakat sekitar sehingga dapat menyumbang konsentrasi kadar kandungan nikel di Stasiun I. Dugaan yang lain juga disebabkan karena letak Stasiun I yang berada pada perbatasan Desa dengan Tapungggaea dan terdapat beberapa pemukiman rumah warga yang berdekatan dengan Stasiun 1. Hal inilah yang kemunginan menyebabkan hanya di stasiun tersebut yang memiliki kadar kandungan nikel dalm air yang lebih tinggi dibanding stasiun lainnya. Hal ini berdasarkan pernyataan Hikmatul (2014) bahwa, kontribusi terbesar konsentrasi logam berasal dari masukan aktivitas masyarakat dan kegiatan penambangan dan perindustrian disekitar lingkungan perairan.

Kondisi perairan pada suatu lingkungan tertentu dapat dilihat dari parameter oseanografi fisik perairan diantaranya seperti suhu, arus, $\mathrm{pH}$ (derajat keasaman), kecerahan dan salinitas. Parameter oseanografi fisik pada dasarnya dapat mempengaruhi konsentrasi logam berat di perairan. Hal ini berdasarkan pernyataan Setyawan et al., (2013) bahwa, suhu dan salinitas serta faktor fisika lainnya sangat mempengaruhi proses kelarutan akan logam-logam berat yang masuk ke perairan. Menurut Ana (2010) bahwa, logam berat dalam suatu lingkungan baik itu air maupun sedimen dapat melalui banyak proses akumulasi yaitu secara fisik, kimia dan biologis. Hal ini diperkuat oleh Hutagalung (1994) yang mengatakan bahwa, penurunan salinitas dan $\mathrm{pH}$ serta naiknya suhu dapat menyebabkan tingkat bioakumulasi logam semakin besar. Sehingga konsentrasi kadar kandungan nikel semakin tinggi.

Hasil pengukuran kadar nikel pada air disetiap stasiun dapat dilihat pada Tabel 6 . Kadar kandungan nikel disetiap stasiun berkisar 0,76-9,72ppm. Kadar tersebut telah melebihi ambang batas yang ditetapkan oleh KMNKLH No. 51 Tahun 2004 tentang batas maksimal cemaran logam berat nikel dalam air untuk biota laut yaitu sebesar $0,05 \mathrm{ppm}$. Hal ini menunjukkan bahwa Perairan Desa Tapuemea telah sangat tercemar. Kadar kandungan nikel dalam sedimen disetiap stasiun berdasarkan standar Internasional baku mutu menurut Dutch Quality Standards for Metals in Sediments telah memasuki sangat tercemar kecuali pada stasiun VII $(79,74 \mu \mathrm{g} / \mathrm{g})$ masuk dalam kategori tercemar sedang. Menurut Darmono (2001) bahwa, tingkat kandungan logam disetiap tempat sangat bervariasi bergantung pada lokasi dan tingkat pencemarannya.

Konsentrasi nikel di stasiun III lebih rendah dibandingkan dengan kadar kandungan nikel di stasiun-stasiun lainnya. Hal ini dimungkinkan karena faktor fisik perairan yang disertai tipe substrat yang berpasir menyebabkan kadar kandungan nikel dalam sedimen rendah. Hal ini berdasarkan pernyataan Sriwahyuni et al., (2015) yang mengatakan bahwa, ukuran butiran sedimen mempengaruhi kadar konsentrasi logam berat di sedimen. Semakin besar ukuran butiran sedimen semakin kecil peluang logam berat terakumulasi didalamnya.

Tingginya konsentrasi nikel dalam sedimen di stasiun VIII disebabkan oleh kondisi stasiun yang cukup tenang, cukup tertutup dan dekat dengan jetty tempat penampungan ore nikel. Selain itu, stasiun I juga memiliki nilai yang cukup tinggi disebabkan terdapat tumpukan batu karang mati yang tersusun secara horizontal digunakan sebagai alat pemecah gelombang sehingga menyebabkan lokasi stasiun I cukup tenang dan tertutup. Kondisi ini menyebabkan sirkulasi air menjadi terbatas sehingga logam berat cenderung terdeposit dan terakumulasi di dasar perairan serta menjadikan kadar nikel meningkat. Hal ini berdasarkan pernyataan Hutagalung (1994) bahwa, logam berat tersuspensi akan cenderung terdeposit ke dasar perairan pada kondisi perairan yang tenang. Menurut Alimah et al., (2014) bahwa, kegiatan penambangan akan memberikan dampak pencemaran dan terakumulasinya logam berat dalam sedimen sehingga dapat memberikan efek toksik.

Secara umum kandungan logam berat pada sedimen lebih tinggi dibanding yang terdapat pada air laut (Alimah et al., 2014). Menurut Priyanto et al., (2008) bahwa, logam berat mempunyai sifat mengikat bahan organik dan mengendap di dasar perairan dan bersatu dengan sedimen sehingga kadar logam berat dalam sedimen lebih tinggi dibanding dalam air. Hal ini diperkuat oleh Bhosale dan Sahu (1991) bahwa, logam berat yang mengendap di dasar perairan akan terakumulasi ke dalam sedimen, sehingga jumlahnya lebih tinggi dibandingkan dengan 
yang terdapat di perairan. Logam berat yang masuk ke perairan akan mengalami pengendapan, pengenceran dan dispersi.

Sedimen di Perairan Desa Tapuemea lebih banyak mengakumulasi logam nikel baik yang berasal dari peluruhan mineral logam secara alami maupun proses geologi yang terdapat di perairan ini dan yang berasal dari limbah atau kegiatan penambangan serta berbagai kegiatan baik di laut maupun di darat. Hal tersebut dapat menyebabkan efek toksik dan pasti akan berdampak buruk bagi kesehatan manusia itu sendiri. Hal ini berdasarkan pernyataan Tirta et al., (2016) bahwa, umumnya nikel bersifat toksik, meskipun dalam jumlah kecil nikel dibutuhkan oleh tubuh, sifat toksiknya akan timbul bila dalam kadar yang relatif tinggi. Nikel jika terdapat dalam jumlah yang terlalu tinggi dapat membahayakan kesehatan manusia disebabkan efek toksik dari logam itu sendiri misalnya menyebabkan kanker paru-paru, kanker hidung, kanker pangkal tenggorokan, kanker prostat, merusak fungsi ginjal, menyebabkan kehilangan keseimbangan, menyebabkan kegagalan respirasi, kelahiran cacat, asma, bronkis dan rusak hati.

Pola sebaran nikel dalam air disetiap stasiun terlihat tinggi di pesisir dan semakin rendah menuju ke arah laut. Terlihat pada Gambar 4 bahwa setiap stasiun memiliki pola warna yang berbeda-beda, dimana pada stasiun I dan VIII memiliki warna yang begitu pekat (coklat tua) ditandai dengan tingkat kadar kandungan nikel yang tinggi $0,23 \mathrm{ppm}$ dan $0,20 \mathrm{ppm}$. Sedangkan pada stasiun yang lainnya, terlihat sebaran warnanya yaitu coklat muda disebabkan kadar kandungan nikel berkisar 0,04-0,07ppm. Perbedaan dan tingginya kadar kandungan nikel disetiap stasiun (Gambar 4) diduga akibat adanya faktor lingkungan maupun jenis sedimen yang berbeda disetiap stasiun serta bias waktu pengambilan sampel yang berbeda. Hal ini berdasarkan pernyataan Darmono (2001) bahwa, suatu lingkungan perairan umumnya akan ditemukan senyawa logam yang keberadaannya dipengaruhi oleh faktor lingkungan seperti suhu, $\mathrm{pH}$, salinitas serta berbagai karakter sedimen. Hal ini diperkuat oleh Tirta et al., (2016) yang mengatakan bahwa, peningkatan logam berat dalam air laut selain disebabkan oleh peningkatan aktivitas disekitar perairan, dapat pula disebabkan oleh rendahnya $\mathrm{pH}$ dan salinitas, tingginya suhu dan masuknya nutrien dari muara ke dalam laut.

Peningkatan kandungan logam berat dalam air di Perairan Desa Tapuemea setiap stasiun diduga disebabkan semakin meningkatnya jumlah penduduk, aktivitas penggalian ore nikel, kegiatan industri dan kegiatan perkebunan kelapa sawit yang lokasinya masuk dalam wilayah pesisir dan dekat dengan laut. Hal ini berdasarkan pernyataan Ana (2010) bahwa, logam berat di perairan kebanyakan disebaban oleh kegiatan antropogenik. Hal ini diperkuat oleh Achyani et al., (2013) yang mengatakan bahwa, tingginya kadar nikel di perairan umumnya disebabkan oleh aktivitas kegiatan manusia, misalnya aktivitas pertambangan, peleburan dan pemurnian nikel. Sumber senyawa logam berat di perairan laut dapat berasal dari berbagai kegiatan, misalnya aktivitas rumah tangga dan limbah pertanian (Rochyatun et al., 2006).

Pola sebaran nikel pada sedimen disetiap stasiun terlihat tinggi di pesisir dan semakin rendah menuju ke arah laut. Setiap stasiun memiliki pola warna yang berbedabeda, dimana pada stasiun VIII memiliki warna yang begitu pekat (coklat tua) ditandai dengan tingkat kadar kandungan nikel yang sangat tinggi 9,72ppm atau setara dengan nilai $9369,39 \mu \mathrm{g} / \mathrm{g}$. Sedangkan pada stasiun yang lainnya, terlihat sebaran warnanya yaitu coklat muda.

Pola sebaran nikel dalam sedimen disebelah Barat pada stasiun I dan sebelah Timur Stasiun VIII menunjukkan kandungan nikel yang sangat tinggi, dimana pada Stasiun I berkisar 6,26ppm dan Stasiun VIII berkisar 9,72ppm. Tingginya konsentrasi nikel dalam sedimen di Perairan Desa Tapuemea karena telah terkontaminasi oleh nikel. Seiring dengan berjalannya waktu maka nikel akan terakumulasi pada sedimen dalam jumlah yang lebih banyak lagi, juga dalam tubuh biota yang hidup dan mencari makan di dalamnya. Berdasarkan Gambar 5 dapat dikategorikan bahwa kualitas sedimen di Perairan Desa Tapuemea telah melebihi nilai ambang batas yang ditetapkan oleh KMNKLH nomor 51 Tahun 2004 untuk biota laut 0,05ppm. Berdasarkan pernyataan IADC/CEDA (1997) bahwa, jika logam berat nikel telah melebihi baku mutu yang ditetapkan pada level bahaya maka perairan tersebut dikatakan telah sangat tercemar. 


\section{Kesimpulan}

Berdasarkan hasil penelitian yang telah dilakukan maka dapat ditarik kesimpulan bahwa:

1. Konsenrarsi kandungan nikel pada sedimen dan air di Perairan Desa Tapuemea Kabupaten Konawe Utara telah sangat tercemar dan melebihi nilai ambang batas dengan kisaran 0,76-972ppm atau setara

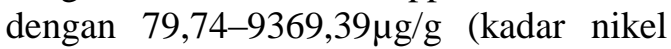
dalam sedimen) dan berkisar 0,040,23ppm (kadar nikel dalam air).

2. Pola warna yang berbeda-beda menunjukkan tingkat konsentrasi nikel yang berbeda-beda, dimana semakin coklat tua menandakan konsentrasi nikel semakin tinggi. Sebaliknya, semakin coklat muda menandakan tingkat konsentrasi nikel yang semakin menurun (rendah).

\section{Daftar Pustaka}

Achyani, R., Weliyadi, E.p dan Rismawati. 2013. Analisis dan Evaluasi Kontaminasi Logam Berat di Sedimen, Air dan Rumput Laut Euchema cottoni di Kota Tarakan. Jurnal Harpodon Borneo. Vol. 6 (1): 1-11.

Ahmad, F. 2009. Tingkat Pencemaran Logam Berat dalam Air Laut dan Sedimen di Perairan Pulau Muna, Kabaena dan Buton Sulawesi Tenggara. Makara, Sains. LIPI. Vol. 13(2): 117-124.

Alimah., Ikhwan, Y.S. dan Amin, B. 2014. Analisis Logam Berat $\mathrm{Ni}, \mathrm{Mn}$ dan $\mathrm{Cr}$ pada Air dan Sedimen di perairan Pantai Pulau Singkep Kepulauan Riau. Jurnal Dinamika Lingkungan Indonesia. Vol. 1 (2): 116-123.

Amin, B., Evy, A dan Mikel, A. 2011. Distribusi Spasial Logam $\mathrm{Pb}$ dan $\mathrm{Cu}$ pada Sedimen dan Air Laut Permukaan di Perairan Tanjung Buton Kabupaten Siak Provinsi Riau. Jurnal Teknobiologi. Vol. 2 (1): $1-8$.

Ana, Y.A. 2010. Analisis kandungan Logam Berat $\mathrm{Pb}, \mathrm{Cd}$ dan $\mathrm{Hg}$ pada Kerang Darah (Anadara granosa) di Perairan Bojonegara, Kecamatan Serang. Institut Pertanian Bogor. Bogor. Hal. 1-32.

Bhosale, U dan Sahu, K.C. 1991. Heavy Metals and Pollution Arround the Island City of Bombay, India. Part II: Distribution of Heavy Metals Between Water, Sus pended Particle and
Sediment a Polluted Aquatic Regime. Journal Chemistry Geology. Vol. 90: 285-305.

Cahaya, I. dan Budiawan. 2015. Studi Pelepasan Kadmium (Cd) dan Nikel (Ni) pada Sedimen secara Metode Toxicity Characterisic Leaching Procedure (TCLP) dan Uji Sifat Bioakumulasinya Melalui Simulasi pada Cyprinus carpio. Jurnal Sains Dasar. Vol. 4 (1): 55-64.

Carlen, M.M. 2017. Pengaruh Parameter Fisika dan Kimia Terhadap Kehadiran Ikan Lompa (Thryssa baelama forsskal) di Perairan Pantai Apui Kabupaten Maluku Tengah. Jurnal Perikanan. Universitas Gajah Mada. Vol. 19 (2): 61-66.

Darmono. 2001. Lingkungan Hidup dan Pencemaran. Hubungan dengan Toksikologi Senyawa Logam. Universitas Indonesia. Jakarta.

Effendi, H. 2003. Telaah Kualitas Air Bagi Pengelolaan Sumber Daya dan Lingkungan Pencemaran. Kanisisus. Jogyakarta. Hal. 1-25.

Esye, B.L., Amin, B. dan Nedi, S. 2015. Analisis Konsentrasi Logam Krom (Cr) dan Nikel (Ni) di Perairan Pantai Barat Kabupaten Karimun Provinsi Kabupaten Riau. Fakultas Perikanan dan Ilmu Kelautan. Universitas Riau. Hal. 1-8.

Hikmatul, D.A. 2014. Konsentrasi Logam Berat Timbal $(\mathrm{Pb})$ pada Air, Sedimen, dan Rumput Laut Sargassum polycystum di Perairan Pulau Pari, Kepulauan Seribu. Institut Pertanian Bogor. Bogor. Hal. 1-22.

Hutagalung HP. 1994. Kandungan Logam Berat dalam Sedimen di Kolam Pelabuhan Tanjung Priok, Jakarta. Prosiding. Makalah Penunjang Seminar Pemantauan Pencemaran Laut, P3O-LIPI. Jakarta.

IADC/CEDA. 1997. Environmental Aspects of Dredging-Conventions, Codes and Conditions: Marine Disposal. International Association of Dredging Companies (IADC) and Central Dredging Association (CEDA). Netherlands. Hal. 1-71.

Ioramullah, W. 2014. Studi Konsentrasi Nikel (Ni) dalam Sedimen dan Hubungannya dengan Struktur Komunitas 
Makrozoobenthos di Perairan Pesisir Desa Totobo Kec. Pomalaa Kab. Kolaka. SKRIPSI. Fakultas Perikanan dan Ilmu Kelautan. Universitas Halu Oleo. Kendari.

Kementrian Negara Kependudukan dan Lingkungan Hidup. 2004. Keputusan No.51/KMNKLH/2004 tentang Pedoman Penetapan Baku Mutu Air Laut untuk Biota Laut. Sekretariat Negara. Jakarta.

Pradifta, G.S., Yunasfi dan Leidonald, R. 2016. Bioakumulasi Logam Berat $\mathrm{Cd}$ dan Pb Pada Api-Api (Avicennia alba) Di Desa Bagan Deli Kecamatan Medan Belawan. Universitas Sumatra Utara. Medan. Hal. 1-11.

Priyanto, N., Dwiyitno, F Dan Ariyani, F. 2008. Kandungan Logam Berat (Hg, Mn, Cd Dan Ni) pada Ikan, Air dan Sedimen di Waduk Cirata, Jawa Barat. Jurnal Pascapanen dan Bioteknologi Kelautan dan Perikanan. Vol. 3 (1).

Rukminisari, N., Nadiarti dan Awaludin, K. 2014. Pengaruh Derajat Keasaman (pH) Air Laut Terhadap Konsentrasi Kalsium dan Laju Pertumbuhan helmida sp. Ilmu Kelautan dan Perikanan. Vol. 24 (1): 28-34.

Rochyatun, E., Taufik, M.K. dan Rozak, A. 2007. Distribusi Logam Berat Dalam Air dan Sedimen di Perairan Muara Sungai Cisadane. Makara, Sains. LIPI. Vol. 10(1): 35-40.

Rompas, R.M., Rumampuk, N.D.C dan Rompas, J.R. 2009. Oseanografi Kimia. PT. Walau Bengkulen.

Said, I., Noor M.J., Upe, A. dan Wahid, A.W. 2009. Penerapan Konsentrasi Logam Berat Krom dan Timbal Dalam Sedimen Estuaria Sungai Matangpondo Palu. Journal Chemica. Vol. 10 (1): 4047.

Setyawan, N., Kariada, N. dan Peniati, E. 2013. Mikro Anotomi Insang Ikan sebagai Indikator Pencemaran Logam Berat di Perairan Kaligarang Semarang. Unnes Journal of Life Science. Vol. 2 (1): 50-58.

Sriwahyuni, A., Tahir, R.L. dan Maricar, F. 2015. Kajian Kontaminan Sedimen di Muara Sungai Jeneberang. Program Studi Teknik Lingkungan. Universitas Hasanuddin. Makassar. Hal. 1-9.
Suryani, M., Nursal dan Febrita, E. 2014. Kandungan Logam Berat Timbal $(\mathrm{Pb})$ dan Kadmium (Cd) pada Anadara granosa di Pantai Nongsa Kota Batam untuk Penyusunan Lembar Tugas Siswa paada Konsep Pencemaran Air di SMA. Universitas Riau. Batam.

Tirta, F.GS., Hidayat, D. dan Septiani, D.P. 2016. Kajian Kandungan Logam Berat Mangan (Mn) dan Nikel (Ni) pada Sedimen di Pesisir Teluk Lampung. Journal Analit: Analiytical and Envinomental Chemistry. Vol. 1 (1): 17-26.

Zaizafun, A.S., Idris, F. dan Dhamar, A.S. 2017. Analisis Kandungan Logam Berat $(\mathrm{Cd}$ dan $\mathrm{Pb})$ pada Air Laut dan Sedimen Laut di Perairan Kota Tanjungpinang. Fakultas Ilmu Kelautan dan Perikanan, Universitas Maritim Raja Ali Haji. Hal. 1-19. 